\title{
ПРОБЛЕМИ ТЕХНІЧНОЇ ЕКСПЛУАТАЦІЇ СУДНОВИХ СТРІЧКОВИХ ТРАНСПОРТЕРІВ
}

\author{
Дрозд О.В. ${ }^{1}$, Сандлер А.К. ${ }^{2}$ \\ 1,2 - Національний університет «Одеська морська академія», м.Одеса, Україна \\ E-mail: ${ }^{1}$ ELENADROZD912@gmail.com, ${ }^{2}$ albertsand4@gmail.com
}

Copyright ( $\odot 2018$ by author and the journal "Automation technologies and business - processes. This work is licensed under the Creative Commons Attribution International License (CC BY). http://creativecommons.org/licanses/by/4.0

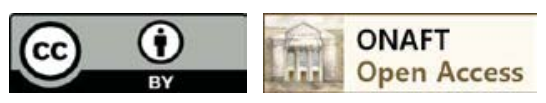

DOI:

Анотація: Розглянуто стрічкові транспортери у складі вантажної системи балкара. Визначено причини відмов вантажного обладнання $i$ їх позапланового ремонту. Наведено економічні складові технічного використання транспортерів і виявлені сучасні проблеми в їх експлуатації та обслуговуванні.

Abstract: Belt conveyors are considered in the composition of the cargo lifting

system of bulk carrier. The reasons for the failure of the cargo equipment and their unscheduled repair are determined. Economic constituents of technical use of transporters are presented and modern problems in their exploitation and maintenance are revealed.

Ключові слова: балкер, судновий стрічковий конвеєр, стрічка, ролик, експлуатація, ремонт, обслуговування.

Keywords: bulk carrier, ship conveyor belt, belt, roller, operation, repair, service.

\section{1. Вступ}

Сучасний балкерний флот має в своєму складі значну частину саморозвантажних суден 3 стрічковими транспортерами безперервного типу. Вантажна система такого балкеру, як правило, включає два або три стрічкових конвеєри, які під трюмами, здвоєний вертикального типу конвеєр-підйомник і стрілу - поперечний стрічковий конвеєр для роботи з берегом.

\section{2. Аналіз літературних джерел і постановка питання}

Робота в жорсткій конкурентній боротьбі за вантажопотоки висуває перед судами цього типу завдання скорочення часу стоянки під обробкою. Одним з варіантів вирішення проблеми є збільшення продуктивності вантажної системи [1].

Продуктивність конвеєра залежить від швидкості руху стрічки і кількості вантажу на ній. Збільшення продуктивності можливо, в першу чергу, за рахунок збільшення швидкості транспортування вантажу на стрічці. При цьому гранична величина швидкості буде обмежена потужністю двигуна.

3 іншого боку, в експлуатації і обслуговуванні суднових конвеєрів закладені такі критерії як експлуатаційна надійність, довговічність і ремонтопридатність. Довговічність суднового стрічкового транспортера забезпечується обгрунтованим вибором його продуктивності і зводиться до правильного вибору швидкості транспортування і площі перерізу вантажного потоку. Зрослі швидкості руху стрічки вже створюють складнощі у забезпеченні надійності і довговічності вантажного обладнання. Стають проблематичними збільшення його термінів служби і міжремонтних періодів експлуатації [2, 3].

\section{3. Мета і задачі дослідження}

Аналіз технічних ризиків і ймовірність відмов суднових стрічкових конвеєрів внаслідок вищевикладеного дозволяють виділити дві основні групи причин позапланового їх ремонту.

До першої слід віднести загоряння стрічкового конвеєра від:

- тертя стрічки об натяжний барабан конвеєра;

- нагрівання поверхні електродвигуна;

- тертя стрічки об заклинений ролик;

- тертя в вузлах.

Друга група причин - це вимушена зупинка стрічкового конвеєра в результаті:

- обриву стрічки; 
- сходу стрічки;

- відмови двигуна;

- перевантаження стрічкового конвеєра;

- заклинювання натяжного барабана;

- заклинювання стрічки.

Таким чином, зрослі швидкості обробки суден, так само як і великі вантажопотоки і розширена номенклатура масового вантажу, що перевозять, створюють критичні умови експлуатації вантажного обладнання даного типу суден.

\section{4. Основні пункти дослідження}

Найбільшого поширення на судах отримала схема роликового конвеєра 3 прогумованою стрічкою, що відрізняється простотою конструкції. За конструкцією прогумованої стрічки, опорних ходових пристроїв і передачі тягового зусилля, це є тип стрічкових конвеєрів, у яких стрічка несе вантаж і одночасно є тягловим елементом.

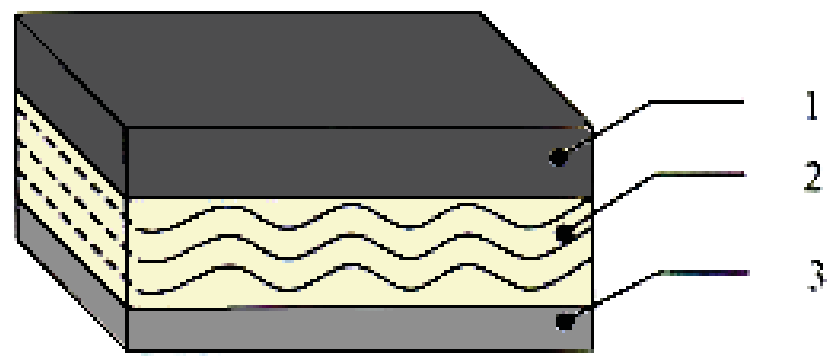

1 - каркас; 2 - робоча поверхня; 3 - неробоча поверхня Рис.1 - Структура транспортерної стрічки

Каркас, як правило, виконують з комбінованих волокон з металевими кордами, так як від цього залежить міцність стрічки на розрив. Робоча поверхня - комбінована, 3 прогумованої тканини, 3 нанесенням профілю для перешкоджання ковзання вантажу. Неробоча поверхня також виконується з каучуку, але зазвичай без профілю, так як своєю стороною звернена до приводного барабану.

Стрічка при русі робить коливання у вертикальній і горизонтальній площинах, що викликає розсипання вантажу, пошкодження країв стрічки і додаткові витрати енергії. Коливання в вертикальній площині знижують зменшенням відстані між опорами, а в горизонтальній для центрування стрічки ставлять через 5 ... 6 звичайних опор одну опору з роликами, здатними відхилятися по ходу стрічки на кут $2 \ldots 3$. При вигині стрічки на барабані внутрішні шари їі стискаються, а зовнішні піддаються розтягуванню. Між шарами виникають дотичні напруження. Вони тим більше, чим менше діаметр барабана. Максимальний натяг стрічка має на приводному барабані, тому для зменшення напружень вигину діаметр барабану роблять найбільшим.

Термін експлуатації суднової конвеєрної стрічки багато в чому залежить від:

- товщини гумових шарів;

- кількості тканинних прокладок;

- загальної висоти стрічки;

- транспортних характеристик вантажу.

Транспортні характеристики всієї номенклатури насипних і навалочних вантажів дозволяють виділити наступні їх фізико-механічні властивості і загальні закономірності, що впливають на режим експлуатації і періодичність обслуговування стрічки, а саме [4]:

- об'ємна маса в межах $\gamma=0,6 \ldots 3,0 \mathrm{~T} / \mathrm{M}^{3}$;

- кут природного укосу в штабелі $\rho=35 \ldots 45^{\circ}$;

- коефіцієнт зовнішнього тертя або коефіцієнт тертя об опорні поверхні, при якому вантаж починає ковзати по наклонів площині $f=0,5 \ldots 1$;

- фракційний (гранулометричний) склад матеріалу: пилові $\delta=0,05$ мм, порошкоподібні $\delta=0,05 \ldots 0,1$ мм, дрібнозернисті $\delta=0,1 \ldots 0,5$ мм, середньозернисті $\delta=0,5 \ldots 1$ мм, грубозернисті $\delta=1 \ldots 5$ мм, дрібно кускові $\delta=5 \ldots 10$ мм, середньо кускові $\delta=10 \ldots 160$ мм;

- вологість сипучого вантажу $\psi=2$... 20\%.

Площа поперечного перерізу вантажу на стрічці і ï̈ заповнення залежить як від ширини самої стрічки, так і від об'ємної щільності вантажу і динамічного кута природного укосу, а також кута нахилу роликів і кута нахилу конвеєра. 
Фракційний склад вантажу, так само як і збільшення коефіцієнта тертя, безпосередньо впливає на термін експлуатації стрічки: чим більше фракції вантажу, тим швидше йде знос стрічки. Природна вологість сипучого вантажу, разом 3 підвищеною вологістю тунельного простору при використанні забортної води для промивання стрічки, створюють додаткове навантаження на стрічку і роликові опори при переміщенні зернистого і кускового вантажу, фракції яких при цьому укрупнюються.

\section{5. Економічні складові технічного використання елементів вантажної системи}

В обслуговуванні суднових конвеєрів слід виділити дві основні складові: обслуговування стрічки на всьому протязі і обслуговування численних напрямних і підтримуючих роликів в складі транспортерної підвіски кожного конвеєра.

Найбільш дорогим і швидко зношуються елементом стрічкових конвеєрів є стрічка, вартість якої зазвичай становить (65 ... 75)\% вартості всього конвеєра, а термін служби рідко перевищує 1,5 року, в результаті чого істотно знижується рентабельність конвеєрного транспортера.

Передчасний вихід з ладу суднової конвеєрної стрічки обумовлений ії бічними зсувами, що викликає знос бортів стрічки, переломами поздовжнього профілю на роликових опорах і абразивним впливом переміщуваного вантажу. Абразивна дія проявляється тим сильніше, чим вище швидкість руху стрічки.

Практично після кожної перевантажувальної операції тунельні мотористи змушені проводити ремонт окремих ділянок стрічки. 3 огляду на велику її протяжність, ця процедура трудомістка і довгострокова.

Застосування забортної води для замивання стрічки від залишків вантажу створює підвищену вологість в тунельному просторі, важкі умови праці для тунельних мотористів, а також погіршує умови експлуатації роликів в складі роликових опор конвеєра. Ролики, а їх кількість обчислюється сотнями, при інтенсивній експлуатації стрічки відчувають великі динамічні навантаження, і в умовах підвищеної вологості схильні до інтенсивної корозії, що вимагає інтенсивного режиму їх змащування. У таких суднових умовах експлуатації доцільно було б застосування футерованих або роликів, які вкриті гумою, але при цьому незрівнянно зросте економічна складова.

\section{6. Висновки}

Таким чином, багатофакторний аналіз експлуатації стрічкових транспортерів в жорстких суднових умовах дозволяє виділити два основні актуальні завдання, що впливають на ефективність їх технічного використання:

- збереження транспортерної стрічки конвеєра при перевантаженні номенклатурних вантажів протягом усього періоду експлуатації;

- збільшення міжремонтного періоду роликових опор.

\section{Список використаних джерел}

[1] Журавлев Н.П. Транспортно-грузовые системы / Н.П. Журавлев, О.Б. Малин // - М.: УМНЦ, $2005 .-629$ с.

[2] Ивченко, В.Н. Беспросыпные ленточные конвейеры / В.Н. Ивченко, С.В. Куров // - М.: Горная Промышленность. - 2005. - №4.

[3] Конвейеры: Справочник / Р. А. Волков, А. Н, Гнутов, В. К. Дьячков и др. Под общ. ред. Ю. А. Пертена // - Л.; Машиностроение, 1984. - 367 с.

[4] Зелинский, О.В. Справочник по проектированию ленточных конвейеров / О.В. Зелинский, А.С. Петров // - М.: Машиностроение, 1986. - 500 с.

\section{References}

[1] Zhuravlev, N. P., and O. B. Malyn. Transportno-Hruzovye Systemy. M.: UMNTs, p. 629, 2005.

[2] Yvchenko, V.N., and S.V. Kurov. Besprosypnye lentochnye konveyery. M.: Hornaya Promyshlennost’, №4, 2005.

[3] Volkov, R.A., Hnutov, A.N., D’yachkov, V.K. y dr. Konveyery: Spravochnyk. Pod obshch. red. Yu. A. Pertena. L.: Mashynostroenye, p. 367, 1984.

[4] Zelynskyy, O.V., and A. C. Petrov. Spravochnyk po proektyrovanyyu lentochnykh konveyerov. M.: Mashynostroenye, p.500, 1986. 